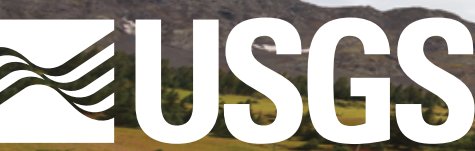

science for a changing world

Prepared in collaboration with U.S. Forest Service, Bureau of Land Management, U.S. Environmental Protection Agency, Colorado Division of Reclamation Mining and Safety, Colorado Department of Public Health and Environment, and Animas River Stakeholders Group

\title{
Geological and Geophysical Data for a Three-Dimensional View Inside the San Juan and Silverton Calderas, Southern Rocky Mountains Volcanic Field, Silverton, Colorado
}

This study integrates geological and geophysical data important for developing a three-dimensional (3D) model of the San Juan-Silverton caldera complex. The project aims to

- apply state-of-the-art geophysical data processing techniques to legacy data;

- map subsurface lithologies, faults, vein structures, and surficial deposits that may be groundwater flow paths;

- better understand geophysical response of mineral systems at depth; and

- provide geological and geophysical frameworks that will inform mining reclamation decisions and mineral resource assessments.

\section{Introduction}

The San Juan-Silverton caldera complex located near Silverton, Colorado, in the Southern Rocky Mountains volcanic field is an ideal natural laboratory for furthering the understanding of shallow-to-deep volcanic-related mineral systems. Recent advances in geophysical data processing and threedimensional (3D) model construction will help to characterize shallow properties important for understanding surface water and groundwater quality issues and will also improve knowledge of deep geological structures that may have been conduits for hydrothermal fluids that formed mineral deposits (fig. 1). The study has general applications to mineral resource assessments in other areas of the world and to identifying possible groundwater flow paths and associated geochemistry important in abandoned mine lands cleanup.

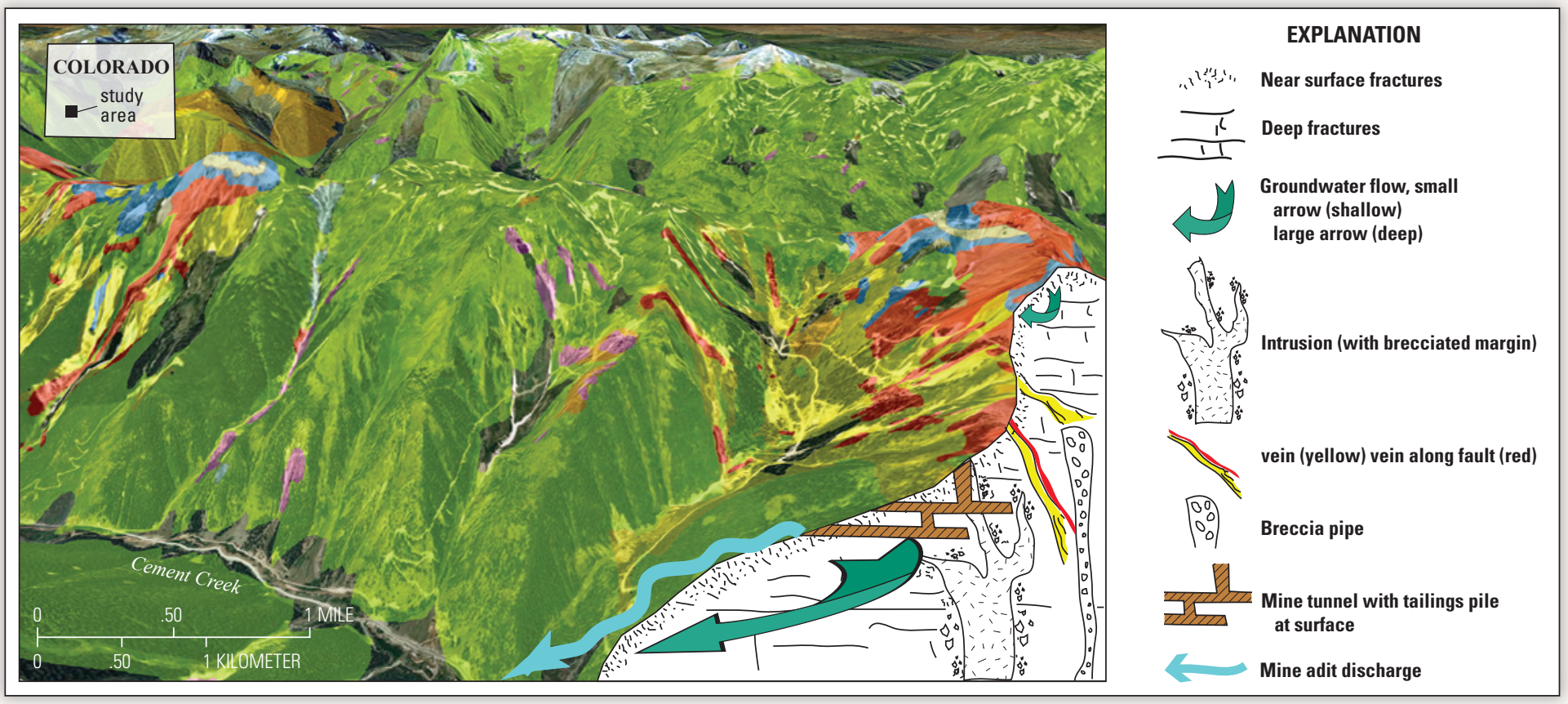

Figure 1. Three-dimensional (3D) view west across upper Cement Creek (lower left) in Silverton, Colorado, study area. Mapped alteration from Bove and others (2007) draped on terrain. Alteration mapped in green are weakly altered rocks with acid neutralizing capacity in some places because of calcite. Alteration mapped in red, yellow, pink, and blue are areas of intense alteration, often containing pyrite and having acid-generating potential. Intensely altered areas are sometimes associated with economic mineralization. Conceptual cutaway of mountain (lower right) shows an example of the complexity of geologic and mining features that influence hydrologic flow paths that geophysics in this study will be used to interpret and map in 3D. 
Silverton, Colorado, is the site of a spectacular succession of igneous rocks that formed beginning about 35 million years ago (Ma). Base metals (copper, lead, and zinc) and precious metals (silver and gold) mined from the late 1870s to 1991 owe their existence to a 25-million-year cycle of igneous activity. The presence of economic, base, and precious metal deposits within a complex geological setting were largely responsible for stimulating studies by the U.S. Geological Survey (USGS) conducted during the early 20th century. The focus of investigations in the late 20th and 21 st centuries have broadened in scope to include abandoned mine lands (AML) investigations. The legacy of hard rock mining in headwater catchment areas caused environmental challenges for local communities and downstream water resource users. The Gold King Mine, located a few kilometers north of Silverton, illustrates the potential environmental effects of abandoned mines. On August 5, 2015, during reclamation efforts at the Gold King Mine, a breach of collapsed workings sent approximately 3 million gallons of acidic and metal-rich mine water into the upper Animas River, a tributary to the Colorado River Basin (fig. 2). Miningrelated sources of metals and acidity add to geological sources of metals in surface water and groundwater. Weathering processes of altered and mineralized rock have been a source of acid rock drainage that have been ongoing for millennia.

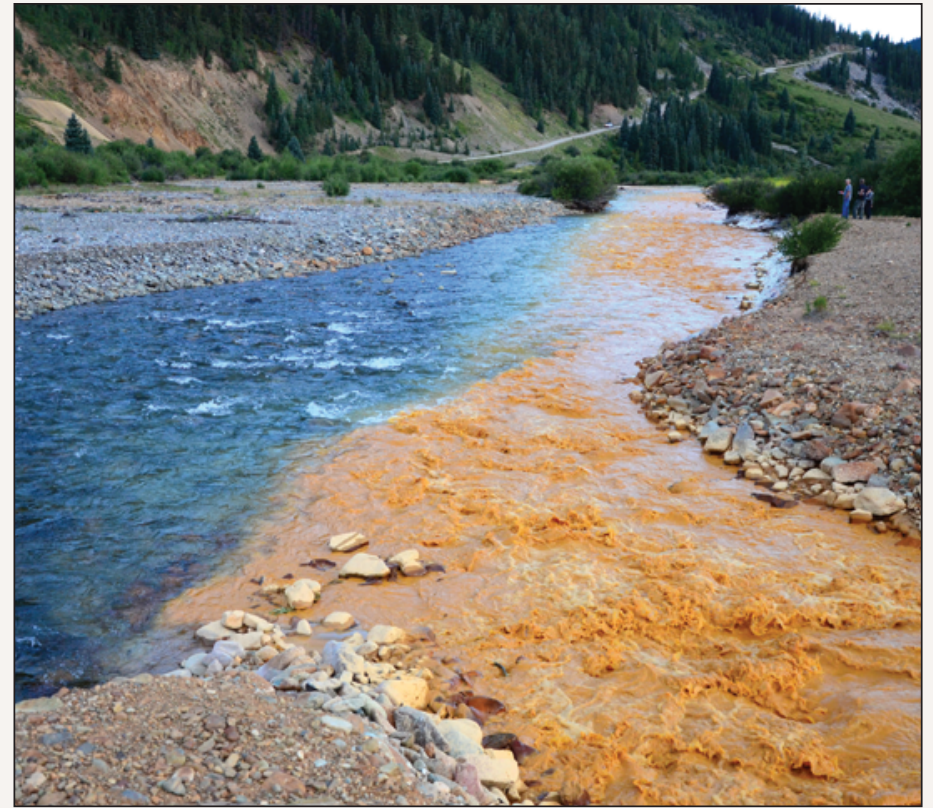

Figure 2. View south of Animas River and Cement Creek confluence. Orange hue in Cement Creek is from abundant iron in Gold King Mine water released on August 5, 2015. (Photograph by Andrea Kron, parttime resident of Silverton, Colorado)

\section{What is a Caldera?}

Silverton, Colorado, is located within two nested calderas (San Juan and Silverton calderas). Calderas are collapsed volcanoes that result when magma is erupted along a ring fault zone at a volcanic margin (fig. 3). The ring fault zone, also called a structural margin, can be circular to elliptical, greater than 15 kilometers in diameter, and extend several kilometers into the crust. Rocks overlying the magma chamber (caldera roof) that were at the surface of the volcano prior to eruption, collapse into the void created during eruption of the magma chamber. The volcano-tectonic upheaval during caldera formation causes rocks adjacent to the volcano to be highly fractured and faulted. Upwelling or resurgence of new magma beneath the intracaldera volcanic fill, pushed up and domed the center of the caldera area and caused additional fractures and faults to form. The caldera-related volcano-tectonic structures were flow paths for hot fluids that deposited base and precious metals.

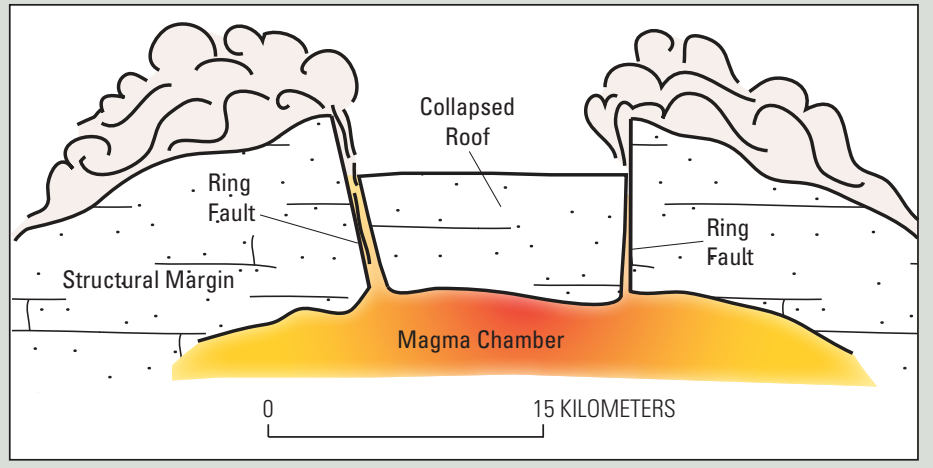

Figure 3. Conceptual cross section of caldera-forming eruption.

\section{Data For Developing a 3D Model}

\section{Geology and Alteration Maps}

Legacy and new datasets will be important for developing a 3D geological and geophysical model. Digital geologic and alteration maps of the study area were completed as part of the USGS AML study conducted between 1996 and 2001 (Bove and others, 2007; von Guerard and others, 2007; Yager and Bove, 2007). These maps along with other geologic mapping are useful to interpret geophysical signatures of geologic units, alteration types, faults, vein structures, and mineralized systems. In addition, geologic cross sections and structural data are used to construct a 3D model of geology and alteration. 


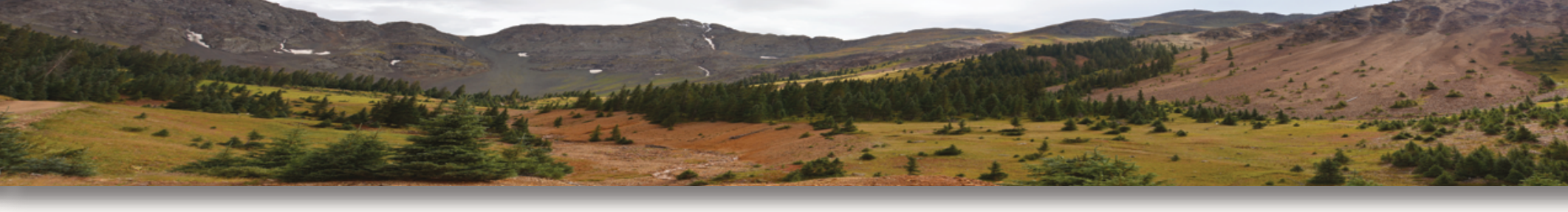

\section{Airborne Geophysical Data}

An airborne electromagnetic (AEM) and magnetic survey was flown in 1999 as part of the AML study (Smith and others, 2007; Anderson and others, 2018). New and improved interpretations of these legacy data are now possible using state-of-art geophysical data processing methods that were previously unavailable. Reprocessing these data will aid in mapping subsurface lithologies and interpreting electrical conductivity signatures and magnetic properties of rocks, sediments, and geologic structures in relation to mine workings and associated mineral deposits. The magnetic and electromagnetic (EM) response of the mineral systems can be measured and modeled in 3D in our project to help characterize mineral deposits in this and similar geologic settings around the world.

\section{Electromagnetic Data}

Electromagnetic properties of rocks and sediments vary depending on minerals present, moisture content, and percentage of clay minerals. Rocks and sediments that have sulfide minerals can be electrically conductive. Dry bedrocks lacking sulfide minerals tend to have low conductivity. Wet bedrocks and clays containing water in their crystal structure can exhibit intermediate conductivity because of conduction through pore fluids and along clay mineral surfaces. Electrical properties of mineralized systems, such as those that formed in the Silverton caldera complex, can be imaged using EM methods. The Silverton AEM survey was flown using a helicopter that towed an EM transmitter and receiver, which measured the conductivity of the material being traversed (fig. 4). The maximum depth of penetration of the EM survey was about 150 meters.

\section{Magnetic Data}

Magnetic properties of rocks vary depending on minerals present, mostly magnetite, a common accessory mineral in igneous rocks. In a caldera setting, magnetite can be produced or destroyed as hydrothermal fluids alter the surrounding rock. Aeromagnetic anomalies are caused by two kinds of magnetism: induced and remanent. The induced component occurs when magnetic material is affected by a primary magnetic field. The remanent component is inherited in a rock on removal of a magnetic field and is dependent on the thermal, mechanical, and magnetic history of the rock. The induced component is mostly determined by the magnetic susceptibility of a rock, which is a quantitative measure of how well a material can be magnetized in the presence of an applied magnetic field. In general, rocks with higher magnetite content have higher magnetic susceptibility. Thus, the rocks and mineral systems in the San Juan-Silverton caldera complex can be expected to produce aeromagnetic highs and lows because of rocks with contrasting magnetic susceptibility. An aeromagnetic map of part of the study area is shown in figure 5. In this environment, these data are sensitive to depths less than 5 kilometers.

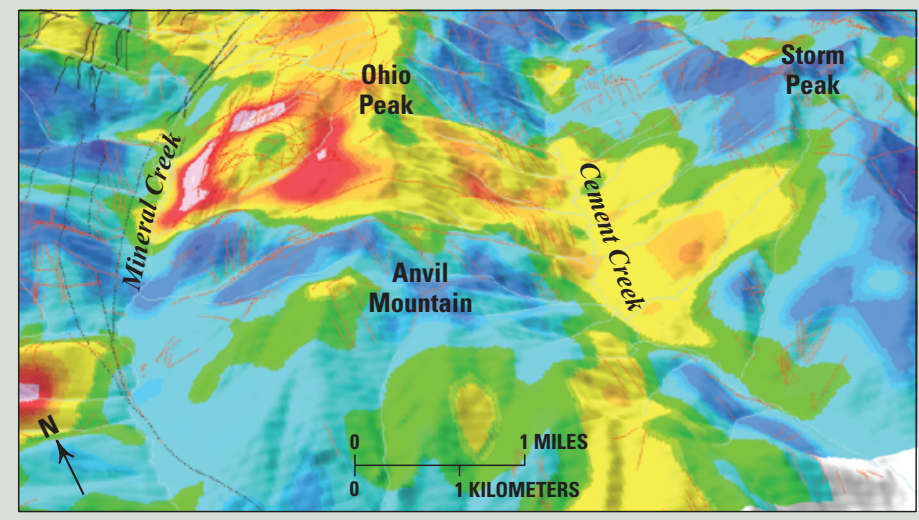

Figure 4. Apparent conductivity from airborne electromagnetic survey. Bright colors are conductive areas. Solid and dashed black lines (faults); dashed red lines (veins).

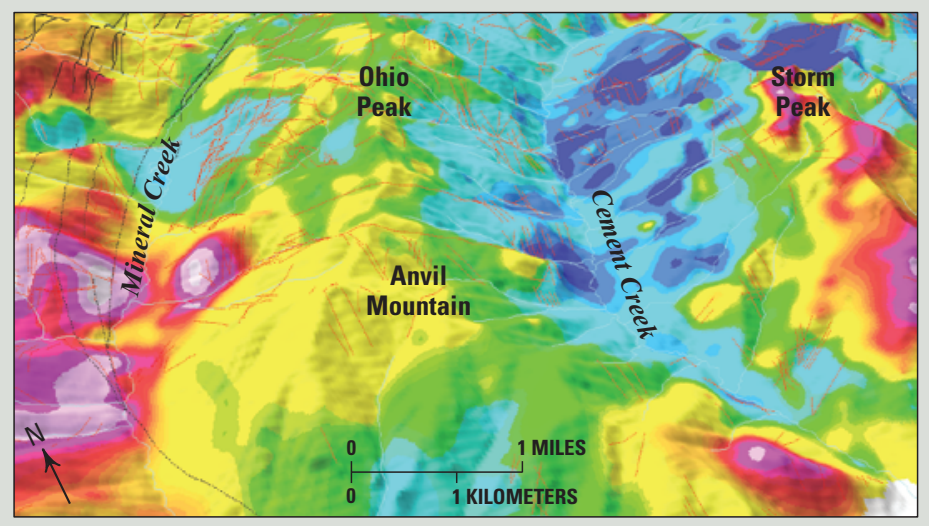

Figure 5. Magnetics from airborne electromagnetic survey. Bright colors are magnetic areas. Solid and dashed black lines (faults); dashed red lines (veins). 


\section{Magnetotelluric Data}

We began collecting new magnetotelluric (MT) data in 2018 (fig. 6). The MT method is a passive groundbased electromagnetic technique that investigates subsurface electrical conductivity at depths of tens of meters to tens of kilometers. It does so by measuring time variations in Earth's electric and magnetic fields. Worldwide lightning activity and geomagnetic micropulsations from solar wind-charged particles interacting with Earth's magnetosphere provide the main source of signal used by the MT method. EM properties of rocks and sediments for the MT method are the same as described in the Electromagnetic Data text box. The MT data help to characterize the electrical conductivity of mineralized caldera structures and adjacent rocks to much greater depths but that overlap depths imaged by the AEM data. The MT information is also useful in interpreting causes of high conductivity signatures where groundwater flow through volcanic rocks might have higher concentrations of total dissolved solids attributed to bedrock weathering processes.

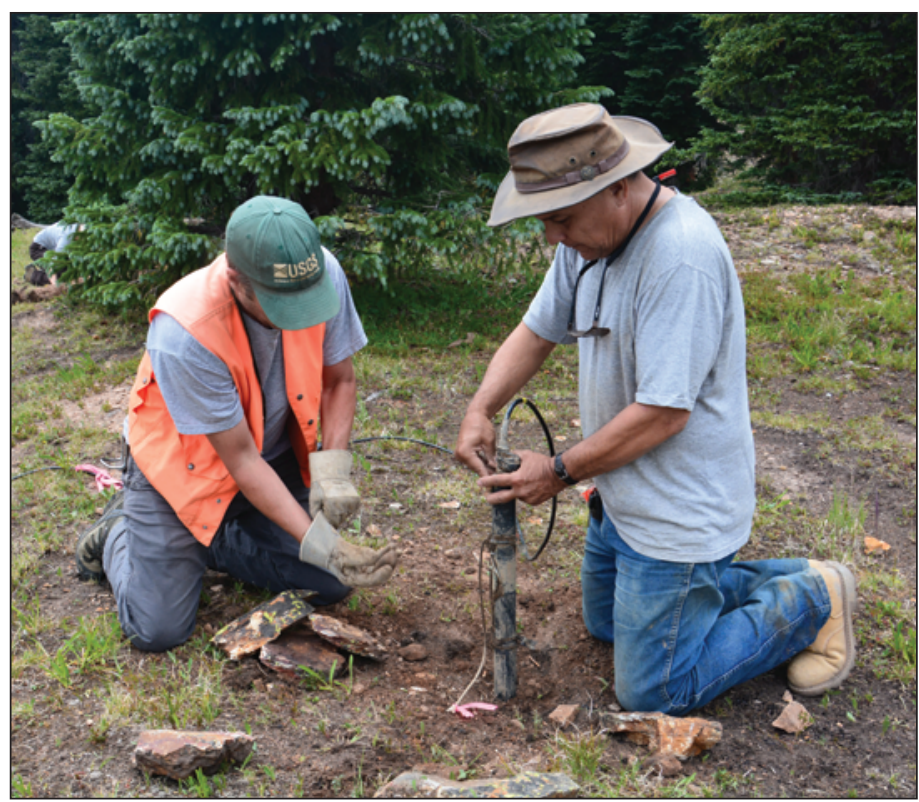

Figure 6. Magnetotelluric field team installing a coil sensor. (Photograph by Douglas Yager, USGS).

\section{Summary}

Integration of geological and geophysical data will enable construction of a 3D geological and geophysical model of the caldera complex permitting new interpretations about economic mineralization that are applicable in similar geological environments in other parts of the world. The model will also allow interpretation of electrically conductive structures and deposits that are permissive groundwater flowpaths and conduits for acidic and metal-rich water important for mine reclamation decisions and abandoned mine cleanup.

\section{References}

Anderson, E.D., Deszcz-Pan, M., Yager, D.B., and Smith, B.D., 2018, High resolution helicopter-borne magnetic and electromagnetic survey Eureka Graben area, Colorado September 1999: U.S. Geological Survey data release, https://doi.org/10.5066/F75D8R1W.

Bove, D.J., Yager, D.B., Mast, M.A., and Dalton, J.B., 2007, Alteration map showing major faults and veins and associated water-quality signatures of the Animas River watershed headwaters near Silverton, southwest Colorado: U.S. Geological Survey Scientific Investigations Map 2976, 18-p. pamphlet, 1 plate, scale 1:24,000.
Smith, B.D., McDougal, R.R., Deszcz-Pan, M., and Yager, D.B., 2007, Helicopter electromagnetic and magnetic surveys, chap. E4 of Church, S.E., von Guerard, P., and Finger, S.E., eds., Integrated investigations of environmental effects of historical mining in the Animas River watershed, San Juan County, Colorado: U.S. Geological Survey Professional Paper 1651, p. 231-254.

von Guerard, P., Church, S.E., Yager, D.B., and Besser, J.M., 2007, The Animas River watershed, San Juan County, Colorado, chap. B of Church, S.E., von Guerard, P., and Finger, S.E., eds., Integrated investigations of environmental effects of historical mining in the Animas River watershed, San Juan County, Colorado: U.S. Geological Survey Professional Paper 1651, p. 17-38.

Yager, D.B., and Bove, D.J., 2007, Geologic framework, chap. E1 of Church, S.E., von Guerard, P., and Finger, S.E., eds., Integrated investigations of environmental effects of historical mining in the Animas River watershed, San Juan County, Colorado: U.S. Geological Survey Professional Paper 1651, p. 107-140.
By Douglas B. Yager, Eric D. Anderson, Brian D. Rodriguez, Maria Deszcz-Pan, and Bruce D. Smith 